\title{
THE EFFECT OF THE SIZE OF THE FACILITIES GRANTED BY BANKS ON THE AMMAN STOCK EXCHANGE INDEX
}

\begin{tabular}{|c|c|}
${ }^{1}$ Issa Ahmad Mahmoud Swiety & ${ }^{I}$ Zarqa University, Zarqa, Jordan \\
\hline
\end{tabular}

This research aims to measure the effect of the size of facilities granted by banks on the Amman Stock Exchange Index. The study included all the 16 licensed banks operating in Jordan during the period 2004 up to 2015 through using statistical analysis (SPSS) which shows a positive relationship that statistically significant between the size of the granted facilities and the stocks index.

KEYWORDS: Size of The Facilities, Amman Stock Exchange Index

\section{INTRODUCTION}

The banking systems are one of the most important inventions of the modern societies due to the fundamental role they play, through their mediating role among depositors who make up the sid e of money supply in the banking system and the borrowers who make up the demand side of these funds.

The banking systems represent an important mechanical to collect the savings and convert them into investments along their work to attract the foreign investments and channel them to finance the most efficient, productive and profitable projects through the various types of credit facilities provided by it.

Therefore, it is logical that effect of the increasing size of the facilities of all the services and banking facilities which are provided by the banking systems on the profits of the banks to positively affect their market value, which is appeared through influencing their index sector in the Amman stock Exchange.

\section{THE PROBLEM OF THE STUDY}

The bank credit has an Effectiveness Banking importance, where its generated return represents the major centerpiece of revenue for any bank whatever are the numbers of its other sources are or varied, without it the bank will lose its work as financial mediator in the national economy and the primary objective of the banks to provide credit facilities to the companies is to invest their money to achieve the desired yield, and the positive impact reflect in these profits on the market value of these banks and to these companies and which 
reflected in rising share price in the financial market, and which appears in the value of the sector index to which these banks belong, and thus the researcher studies the possibility of a trace in the volume of the credit facilities granted to the benchmark of Amman, and therefore the researcher is seeking to prove the following hypothesis:

There is no statistically significant effect on the size of the credit facilities granted to Amman Stock Index.

\section{THE IMPORTANCE OF THE STUDY}

The importance of the study being shed light on the importance of the role playedby the banks in influencing the economy and through what they are granting of credit facilities to various economic sectors, and to know the reflection of the size of these facilities on the Amman Stock Exchange Index considering that these indicators are the mirror of the performance of these banks.

\section{OBJECTIVES OF THE STUDY}

The study aims at identifying the relationship between the size of the facilities granted to certain sectors of the economy by the licensed banks in Jordan on the Amman Stock Exchange in the period (2004 until 2015), where it will rely on the historical data on the banking facilities size given to these sectors, which have been obtained from the website of the Central Bank of Jordan and the Amman Stock Exchange Index and which have been obtained from the website of the Amman Financial Market.

\section{PREVIOUS STUDIES}

1. A study (Zoubi, Bashir, 200) entitled "the impact of economic flows on the stock prices and trading volume in the Amman Stock Exchange for the period (1978-1998).

2. The study aimed at investigating the impact of macroeconomic variable on the Amman Financial Market Index, where he addressed all of (The Gross National Product), the interest rate, the exchange rate, the money supply, and the interest rates on the timedeposits .

3. The study concluded that the Amman Financial markets respond to the combined economic variables, while there is no relationship between each independent variable, except in the case of delaying the general index of the general index of the market, and the function of the Amman financial market is stable during the period (1978-1998).
4. The Study of (Fyoumi, Nidal, 2003) entitled "the impact of the emerging markets properties on Tests.

5. The study aims at measuring the efficiency of the Amman Exchange by using the markets index for the period (1993-2000), where the focus was on non-linear behaviors issues in the stock returns and not trade repeating in addition to the investigation of the impact of the structural and the organizational changes in the Amman Stock Exchange (ASE) starting in (1997) to improve the efficiency of this market.

6. A result was reached by taking the (ASE) properties as an emerging tock that has a significant impact on the tests, as well as developments in the Amman Stock Exchange starting from (1997) have positive impact that was reflected on the efficiency of the market in this period.

7. Study (Malawi, AlMajali, 2003) entitled "the Credit Banking Effect on the Economic Activity" by using the Self Model Regression Vector (A Jordan Case Study (1970-2003) (page number 125-143, Mutah University)

8. Study (Metas, Rami 2004) "influencing factors on the stock exchange mechanisms of the financial papers.

9. This study aimedat investigating the factors influencing the Egyptian Finance Papers Stock Markets Mechanisms.

10. The results showed that the most influential factors are the Supply and Demand, transparency, the rumors, the Economic situation and the political climate.

11. Study (Kholood Al Fallit, Ishraf Dr. Faris Abu Muammar 2004) entitled The Banking Facilities on the Different Economic sectors, an applicable study on the Banks working in Palestine"

This search aims at determining the effect facilities on the banking bank working in Palestine on different economic sectors, in addition to know the reality of the banks working in Palestine and what are the most important problems which stand barrier against them in developing the economy.

The previous studies and research which focused on this field, were used. The percentage of the facilities which provided by the banks for every sector alone was used.Accordingly, some results that help in identifying how the working banks in Palestine contribute in the economic development.

The study found out that the banks working in Palestine they have a desire to expand in giving facilities for the various economic sectors, except the Agricultural sector and their interest for safeguards 
which provided by the customer as a basic condition to accept request facilities and the courts in Palestine do not interfere in solving the problems that confronting the banks, and conflicts between banks and the comers customers to pay their facilities helped in weakening the banks to give facilities and weakening the role of the banks in giving facilities and the banks weakness in their effects in economic sectors different.

1. Study (Khaled Al Qadeer, 2005) entitled "the Credit Banking Effect to Fund Imports on the imports in the Kingdom of Saudi Arabia."

The search aims at evaluating the demands function from the imports the Saudi Kingdom's imports using the common integration methodology and segmentation contrast of the error forecasting and the functions pulses response that are built on forum of correcting the error vectors

The common integration's test indicates the existence of a long term balance relation between the imports and the total output and relative prices of the imports and the banking credit to fund the imports.

The segmentation of the error forecasting and the pulses functions responses on the importance of the resulting of the GDP (Gross National Output ), the relative prices of the imports, and the banking credit in financing the imports in the explanation of fluctuations in the function of the total imports.

The functions of the pulses response to the relationship between the direct fluctuationsbetween the gross national output and the banking credit in financing the imports and their fluctuations, while the relationship between the fluctuations in the relative prices and of the imports and the fluctuations in the imports was inverse.

2. Study (Altwaijri, Hamid, 2006) entitled "Influential Factors in the Saudi Stock Market. This study aimed at finding out the factors effecting the stock market in Saudi Arabia and concluded that the most important factors influencing the Saudi stock market are the five basic factors which are the oil prices, the national income, money supply, the interest rates and the inflation rates.

3. Study (Joseph, Dana, 2008) entitled "Determination of Factors Affecting the Amman Financial Market.
This study aimed at identifying the most important factors affecting the per share profit and the factors that sharply affecting fluctuations and determine the effect of interior and foreign factors on the shares profit, and the study's sample was stratified and random from (60) companies listed at market Amman Financial year 2006.

The study has found a statistical and positive relation between the inflation rate and the interest prices and the number of stuff and the shares profit the lack of relationship that has positive statistical relation between the deficit or the surplus of the balance of payments and the size of GDP (Gross National Product) and between the shares profit.

4. Study (Abdul Halim, Hibah, 2009) entitled "the Effect of Cash Policy on the Securities Market," the study aimed at identifying the nature of the relationship between monetary policy and the movement of trading in securities in Egypt. The study concluded that the monetary policy affects the stock market in Egypt.

5. Study (2004, Boyer \& filion, Entitled "the Main Factors Affecting the Canadian oil Stocks Earning and the Companies (ASS) and aimed at evaluating the relation between the earnings of the oil stocks as a follow variable and independent variables such as the interest price, the U.S and Canadian dollar prices, the oil prices the market revenues using the (General Linear Model)

\section{The study features}

This study is regarded as one of the few studies that link between some of the relationship between the size of the facilities granted by the banks of Jordan and their index in the Amman Stock Exchange during the period in question, and this evident through a review of the previous studies.

A table that shows the size of facilities granted since the year 2004 to the year 2015 and the Amman Stock Exchange Index. 


\begin{tabular}{|c|c|c|}
\hline The year & $\begin{array}{c}\text { The size of facilities } \\
\text { granted (JD mn) }\end{array}$ & $\begin{array}{c}\text { Amman Stock } \\
\text { exchange index }\end{array}$ \\
\hline 2004 & 6189 & 2729 \\
\hline 2005 & 7744 & 4259 \\
\hline 2006 & 9761 & 3013 \\
\hline 2007 & 11295 & 3675 \\
\hline 2008 & 13044 & 2758 \\
\hline 2009 & 13317 & 2533 \\
\hline 2010 & 14451 & 2373 \\
\hline 2011 & 15815 & 1995 \\
\hline 2012 & 17829 & 1957 \\
\hline 2013 & 18937 & 2065 \\
\hline 2014 & 19019 & 2165 \\
\hline 2015 & 19021 & 2136 \\
\hline
\end{tabular}

\section{THE HYPOTHESIS TEST}

A describe between the relationship of the independent variable (the size of the facilities) and the dependent variable through the following equation:

$\mathrm{Y}=\mathrm{a}+\mathrm{bx}$

$\mathrm{Y}=4337.87+0.0765 \mathrm{x}$

$\mathrm{Y}=$ the dependent variable (the stock index)

$\mathrm{X}=$ the independent variable ( the size of the facilities granted)

The value $\mathrm{R}$ (correlation coefficient) (76.5\%), and this means that there is positive linear relation that has a statistically strong significant between the size of the facilities granted and the stock index, and also the value of R2 (the coefficient of determination) (58.6\%) and has statistically a significant function and by testing (F) to measure the validity of the model to represent the relationship between the dependent variable ( the stock index) and the independent variable (the size of the facilities). This shows that this model is fit to represent the relationship which reached the value of (F) $4 \%$ and is less level of significance of $5 \%$. This means that there is a relationship between the size of the granted facilities and the stock index, it was found that the facilities granted have been able to explain what accounted for $58.6 \%$ of the changes in the index and the remaining $42.4 \%$ is due to other variables not included in the model.

\section{RESULTS AND RECOMMENDATIONS Results}

It has been found that there is relation between the size of the granted facilities and the indicator of the Amman Stock index where it is logical that the size of the facilities affects the size of the investments, which consequently affect the stock index.

\section{Recommendations}

Conduct field research based on the other factors, not on the size of the facilities, it may be possible to have an impact on the stock index.

\section{REFERENCES}

1. Zoubi, Bashir (200). The impact of macro -economic factors on the overall index of stock prices at the Amman Stock Exchange during the period (19781998), The Management Sciences Studies 27 (2) 32 43.

2. Fayoumi, Nidal (2003). The impact of the emerging markets properties the efficiency tests, an application study on the Amman Stock Exchange.

3. A study (published research) Malawi, Al Majali, 2003) entitled "The Credit Banking Effect on The Economic activity using the self-model Vector (VAR). A Jordan case study (1970-2003). page number (125-143) Mutah University.

4. Metas, Rami (2004) the factors influencing the stock exchange financial mechanisms, an electronic copy.http:// www.tadawul.net/ fo rum/shothread.php?t

5. A PHD Thesis (Kholood Al Fallit, supervision Dr. Faris Abu Muammar 2004) entitled "the Banking Facilities on different economic sectors, an application study on the Banks Working in Palestine".

6. A Study (published research) Khalid AI Q adeer, 2005) entitled: the Effect of the Credit Banking to Finance the Imports on the Imports in the Kingdom of Saudi Arabia - The King Saud University.

7. Altwairi, Hamad (2006). Influential factors in the Saudi stock market: a working paper submitted to the first forum and exhibition of the Saudi stock market, the Saudi university, Suadi Arabia.

8. Joseph, Dana (2008). Determination of the Factors Affecting the Shares profit at the Amman Financial Market, unpublished Master thesis, the Middle East University for high studies.

9. Abdul Halim, GIFT (2009). The Impact of the Monetary Policy on the Financial Securities Markets, an electronic copy, http:// wwwtadawul.net/forum/ showthread.php?t 
10. Factors on common and fundamental Boyer, M Filion, D, (2000) stock returns of the candian oil and CAS companies, CIRANO working papers.

11. Acknowledgement

12. This research is funded by the Deanship of Research in Zarqa University, Jordan. 